\title{
For-Profit College Entry and Cost Efficiency: Stochastic Frontier Estimates vs Two-Year Public and Non-Profit Colleges
}

\author{
G. Thomas Sav \\ Department of Economics, Raj Soin College of Business, Wright State University \\ Ohio 45440, United States
}

Tel: 1-937-775-3070 E-mail: tom.sav@wright.edu

Received: January 01, 2012

Accepted: January 20, 2012

Published: March 1, 2012

doi:10.5539/ibr.v5n3p26

URL: http://dx.doi.org/10.5539/ibr.v5n3p26

\begin{abstract}
This paper provides stochastic frontier cost and (in)efficiency estimates for private for-profit colleges with comparisons to public and private non-private colleges. The focus is on the two-year U.S. higher education sector where there exists the largest and fastest growing entry of for-profit colleges. Unbalanced panel data is employed for four academic years, 2005-2009. Translog cost frontiers are estimated with an inefficiency component that depends upon environmental factors defined by college specific characteristics. More experienced public and private non-profit colleges are found to be more cost efficient relative to the newer entrants. In addition, the newer for-profits exhibit greater efficiency variability but also show some evidence of efficiency gains over the academic years. There is some cursory evidence that for-profit entry is positively correlated, albeit weakly, with greater public college sector inefficiency.
\end{abstract}

Keywords: For-profit colleges, Cost efficiency, Stochastic frontier

\section{Introduction}

Greater international competitiveness accompanied by continuous declines in the tax supported funding of public colleges and universities have created a proliferation of interest in a more market based delivery of higher education. For-profit institutions have increasingly responded. In the U.S., that response is evident in the growth of two-year degree granting for-profit colleges. Over the past two decades, the percentage of for-profit colleges comprising the two-year college sector increased from $12 \%$ to $32 \%$. For-profit entry has also been witnessed in the baccalaureate and graduate degree granting markets, but it has not approached anything near the two-year volume. The overall for-profit market share of has more than tripled over the past two decades. Those who generally praise such growth and argue for more of it contend that it offers increased efficiency encouraged by the for-profit motive of private enterprise. Yet, it is somewhat surprising that there is not substance of empirical evidence existing in support of that contention. Based on operating efficiencies, can for-profit higher education be preferred in substitute to education traditionally provided through publicly owned and controlled colleges?

Therein lies the purpose of this paper. The primary thrust is to investigate possible differences in cost efficiencies of public relative to private for-profit colleges. The focus is on U.S. two-year colleges where there actually exist three institutional sectors, viz., public, private non-profit, and private for-profit colleges. Stochastic cost frontier analysis is applied to estimate the cost structures and inefficiencies pertaining to each sector. The analysis employs unbalanced panel data in each sector over four academic years, 2005-06 through 2008-09.

\section{Applied Background and Methodology}

The inquiry relies on the stochastic frontier methodology rooted in the pioneering work of Aigner, et al. (1977) and Meeusen and van den Broech (1977). Other advances and applications centered on production frontiers are of critical interest, including Kumbhakar, et al., (1991), the Battese and Coelli (1992 and 1995) contributions, and Coelli, et al. (1999). Kumbhakar and Lovell (2003), Coelli, et al. (2005), and Fried, et al. (2008) provide extensive overviews of the literature. Applied studies specific to cost frontiers have examined the U.S. airlines industry (Kumbhakar, 1991), insurance industry (Cummins and Weiss, 1993), hospital care (Fujii and Ohta, 2001; Bradford, et al., 2001; Fujii, 2001), banking (Huang \& Wang, 2001), electricity (Knittel, 2002), nursing homes (Farsi \& Filippini, 2004), crime prevention (Barros \& Alves, 2005), and English football (Barros \& Leach, 2007). Only since 2002 has higher education come into the fold of frontier analysis. The applications include English and Welsh 
universities (Izadi, et al., 2002; Stevens, 2005; Johnes \& Johnes, 2009), Canadian universities (McMillan \& Chan, 2006), and Australian and New Zealand universities (Abbott \& Doucouliagos, 2009). Based on a fairly exhasutive literature review, it is believed that this paper is the first to apply stochastic cost frontier analysis to an inquiry of possible cost inefficiency differences between non-profit and for-profit colleges.

To capture the multiproduct nature of colleges, the stochastic cost frontier is empirically modeled with the approximation flexibility of the translog specification. The more restricted Cobb-Douglas being nested therein is easily testable. Thus, total cost $(C)$ can be defined as

$$
C=\alpha_{0}+\sum_{j} \alpha_{j} Y_{j}+\sum_{k} \beta_{k} w_{k}+\frac{1}{2} \sum_{j} \sum_{l} \alpha_{j l} Y_{j} Y_{l}+\frac{1}{2} \sum_{k} \sum_{m} \beta_{k m} w_{k} w_{m}+\sum_{k} \sum_{j} \xi_{k j} w_{k} Y_{j}+(v+u)
$$

where, $C, Y$, and $w$ are in natural logs and vary by college $i$ over time $t$. University production is represented by the outputs $Y$ and the prices pertaining to the factor of production are denoted by $w$. The standard coefficient $\mathrm{a}_{\mathrm{ij}}=\mathrm{a}_{\mathrm{ji}}$ equalities apply. For the Cobb-Douglas specification, the cross product terms vanish. As is usual, the component error is comprised of the random $v_{i t}$, independently and identically distributed $N\left(0, \sigma_{v}{ }^{2}\right)$, and the nonnegative inefficiency effect, $\mathrm{u}_{\mathrm{it}}$.That is, while college operating costs are subject to random shocks, it is likely that there are other factors affecting the degree to which colleges operate above their minimum "best practice" cost frontier. Such cost inefficiencies can be due to managerial decision-making, as well as, student and labor force characteristics.

Following the Battese and Coelli (1995) specification, the effect of these environmental factors, $z$, on cost inefficiency can be determined as

$$
u_{i t}=\delta_{0}+\sum_{r} \delta_{r} z_{r, i t}+w_{i t}
$$

where, $w_{i t}$ is the truncation of the normal distribution with zero mean and variance $\sigma_{u}^{2}$ truncated at $\delta_{0}+\sum \delta_{r} z_{i t}$. In this formulation, it is only acceptable to proceed with simultaneous estimation of (1) and (2). The log-likelihood function along with the formulated technical efficiency predictions are presented in Coelli, et al. (2005). Under the Battese and Corra (1977) reparameterization of $\sigma^{2}=\sigma_{v}{ }^{2}+\sigma_{u}{ }^{2}$, the estimation of $\gamma=\sigma_{u}{ }^{2} /\left(\sigma^{2}\right), 0 \leq \gamma \leq 1$, serves to measure the relevancy of inefficiency effects in college costs whereas the $u_{i l} \geq 1$ measures the extent to which a college operates above its minimum cost frontier.

In the present empirical implementation, (1) includes two college outputs and two input prices, while (2) is based on four factors along with time specific control variables. The full model is applied to unbalanced panel data spanning four academic years, 2005-06 through 2008-09, of observations on public, private non-profit, and private for-profit colleges defined as postsecondary institutions offering at least an associate degree but less than a bachelor's degree.

\section{Data}

Data are drawn from the most recent releases of the Integrated Postsecondary Education Data System (IPEDS) managed by the U.S. National Center for Education Statistics. The total cost (COST) for each college is the reported annual education and general expenditure. Here, it arises from the annual production of teaching credit hours (TEACHING) generated from student enrollments and institutionally wide research output (RESEARCH). At these two year colleges, research is generally different, but not completely absent, from the scholarly output of universities. It does include occupational and vocational or community service oriented activities and, as such, is an output. In this sense, the receipt of government and private research grants, gifts, and contracts act as a proxy for the college aggregate research output; noting that this measure has been the widely accepted proxy since the seminal multiproduct higher education work of Cohn, et al. (1989).

Two wage variables enter the cost frontier as input prices; average salaries of faculty employed under nine month (SALARY-9MO) and under twelve month (SALARY-12MO) contracts. Among public colleges that division is usually referencing teaching faculty compared to administrative faculty, respectively. Differences could impact cost frontiers. However, in the private sector, the distinction tends to be more of an accounting convention, thereby warranting necessary caution when employed therein.

The inefficiency term includes student and labor force variables. College operating efficiencies are assumed to be affected by academically underprepared students. That can correlate with student income and, in turn, college enrollments that are supported by federal government low income grants. Also, such grants impose additional federally mandated administrative requirements upon colleges. Thus, low income grant revenues (FEDGRANTS) can affect both academic and administrative efficiencies. In addition, institutional efficiencies can be affected by students' academic tenacity. A reasonable IPEDS measure is the graduation rate (GRAD-RATE) defined as the percentage of students graduating within $150 \%$ of the normal time to degree completion. There are also labor force productivity effects. And although it is not possible to include measures associated with support staff, the 
inefficiency term includes the number employed of nine (FACULTY-9MO) and twelve (FACULTY-12MO) month faculty.

Colleges that did not report any cost, credit hour production, or faculty employment were omitted from the sample for that academic year. Table 1 presents the descriptive statistics for the primary variables.

\section{Empirical Estimates}

Maximum likelihood estimates for each of the three sectors are provided in Table 1. Based on likelihood ratios, the full models are statistically favored over the OLS regressions without inefficiency effects $\left(\delta_{\mathrm{i}}\right.$ 's $\left.=\gamma=0\right)$. The ratios also reject the restricted Cobb-Douglas in favor of the translog's flexibility. With all the t-ratios well above two, the coefficients are highly significant in the public college sector. As experienced in other research (e.g., Cohn et al., 1989; Koshal \& Koshal, 1999; Sav, 2004; Lenton, 2008), it is not surprising that the same models do not perform as well in capturing the underlying cost structure of private institutions. Also, in the for-profit sector, $96 \%$ of the institutions did not employ nine month faculty; hence the variable is dropped from that sector. In the public sector, the output and wage coefficients carry the expected positive signs. For both private sectors, the wage coefficients come in negative, perhaps indicating that higher wage payments can be accompanied by cost saving productivity gains. On the matter of scale effects, although not the focus of this inquiry, we note that both the public and private for-profit colleges realize increasing returns while the private non-profit colleges experience decreasing returns.

Examining the inefficiency effects, at the margin, additional faculty employment contributes to greater inefficiency. That is true across sectors and for both nine and twelve month faculty. However, the public sector nine month faculty effect is more than twice that of twelve month faculty employment, whereas in the private non-profit sector, the coefficients are nearly equal with only a somewhat larger inefficiency effect on the twelve as opposed to the nine month faculty side. The effects could certainly arise from the present inability to account for inter-sector differences in teaching loads, faculty governance work, or other work assignments. Also mixed across sectors are the inefficiency effects created by the provision of low income federal grants and the graduation rate of students. There is a positive inefficiency associated with low income federal grants among public and private for-profit colleges. The negative effect among private non-profit colleges suggests they are more efficient in handling the educational and administrative grant issues. With respect to graduation rates, one could expect faster graduation rates via better academic students to improve college operating efficiencies. On the other hand, if improved graduation rates require greater teaching and administrative resources, then inefficiencies could surface. The results support both notions; increased inefficiency among public colleges and increased (although statistically insignificant) efficiency in both private sectors.

Overall, the significance of the gamma estimates is supportive of the non-randomness of the inefficiency effects in the public and private for-profit sectors. However, it represents a greater share of the composed variance among the latter colleges (45\%) relative to public colleges (26\%). Interestingly, in both private sectors, the time specific effects indicate a mix of efficiency improvements and degradation, although individually they are insignificant. In contrast, the public sector has experienced significant inefficiency increases in each time period. A more informative analysis comes from the estimated cost inefficiency scores. These are measured against the minimum cost frontiers and are presented in Table 2.

The score results indicate that on average and by all other statistical measures, public sector colleges are more efficient, or at least less inefficient, than any of their private counterparts. However, as one might expect, there is much greater inefficiency variability among the newer industry entrants, viz., the for-profit colleges. But, the extremely large maximum and median scores in that sector do lend some added concern to the ability of capturing the fundamental cost structure of for-profit colleges, i.e., relative to the public sector. The mean annual inefficiency scores mirror the mixed time effects noted above and reveal the spike occurring in the 2007-08 academic year for public and private colleges. That, of course, is simultaneous with the global financial meltdown, increased unemployment, and the resulting bulge in higher education enrollments and corresponding credit hour production. The large efficiency gain in the for-profit sector can presumably be attributed to the fact that those colleges were already experiencing high levels of operating inefficiencies which then declined with the enrollment driven increased production.

All the colleges under this study are subject to state mandated education and fiscal regulations. Those regulations vary by state throughout the U.S. That raises interest in the possibility of (1) variations in state-by-state inefficiencies and (2) the potential entry responsiveness of for-profit competition to that variability. However, in the present study we have not included measures of state regulatory environments, nor could any such data be located for two-year colleges. Hence with the data at hand, Table 3 makes an attempt at providing some constrained insights on such matters. There, an average public sector inefficiency score is calculated for each state (including outlying 
areas) and compared with the for-profit presence in that state. Two relationships emerge. First, for-profits have located in states where public colleges tend to operate at greater inefficiencies. Whether or not for-profits react to public inefficiencies there is the finding that the average inefficiency is 1.61 in the 32 states where for-profits have entered vs. 1.56 in states without for-profit entrants. Second, among the for-profit college states, greater public college inefficiency begets greater for-profit college competition. For those states, the correlation coefficient between the for-profit sector size and the public college inefficiency is 0.35 . While that is not overwhelming statistical evidence, it suggests that for-profit colleges could possibly be using some more readily obtainable entry decision-making variables that could be correlated with the public college inefficiencies estimated here but masked under data that are unavailable for this study.

\section{Conclusions}

The major purpose of this paper has been to investigate the extent to which there exists operating cost inefficiency differences in non-profit relative to for-profit colleges. To do so, stochastic cost frontiers were estimated for three ownership structures in the U.S. two-year college sector: public, private non-profit, and private for-profit colleges. The frontiers were estimated using unbalanced panel data spanning the four academic years 2005-09. The estimated inefficiency scores indicate that the relatively new for-profit entrants experience significantly higher operating inefficiencies relative to both of the long standing and well experienced public and private non-profit colleges. The time-variation in inefficiencies reveal a continuous efficiency decay among public colleges but some annual efficiency improvements among for-profit, as well as non-profit, colleges. The inefficiency results are of greater variability in the for-profit compared to either the public or non-profit sectors. The results also indicate that public sector inefficiencies exhibit inter-state variations that can possibly be attributed to differences in state-by-state regulatory and fiscal constraints. In the final analysis of the paper there is the finding of some positive correlation between public sector inefficiencies and for-profit entry. That relationship could not be rigorously investigated given the data available for the present study. But with a growing concern over the funding of publicly provided higher education and interest in more market based education, exploring that relationship could prove to be a fruitful avenue for future research.

\section{References}

Abbott, M., \& Doucouliagos, C. (2009). Competition and efficiency: Overseas students and technical efficiency in Australian and New Zealand universities. Education Economics, 17(1), 31-57. http://dx.doi.org/10.1080/09645290701773433

Aigner, D. J., Lowell, C. A. K., \& Schmidt, P. (1977). Formulation and estimation of stochastic frontier production function models. Journal of Econometrics, 6(1), 21-37. http://dx.doi.org/10.1016/0304-4076(77)90052-5

Barros, C. P., \& Alves, F. P. (2005). Efficiency in crime prevention. International Advances in Economic Research, 11(3), 315-328. http://dx.doi.org/10.1007/s11294-005-6660-z

Barros, C. P., \& Leach, S. (2007). Technical efficiency in the English football association premier league with stochastic cost frontier. Applied Economics Letters, 14(10), 731-741. http://dx.doi.org/10.1080/13504850600592440

Battese, G. E., \& Coelli, T. J. (1992). Frontier production functions, technical efficiency and panel data: With application to paddy farmers in India. Journal of Productivity Analysis, 3(1/2), 153-169. http://dx.doi.org/10.1007/BF00158774

Battese, G. E., \& Coelli, T. J. (1995). A Model for technical inefficiency effects in a stochastic frontier production function for panel data. Empirical Economics, 20(2), 325-332. http://dx.doi.org/10.1007/BF01205442

Battesse, G. E., \& Corra, G. S. (1977). Estimation of production frontier model: With application to the pastoral zone of Eastern Australia. Australian Journal of Agricultural Economics, 21(3), 169-179.

Bradford, W. D., Kleit, A. N., Krousel-Wood, M. A., \& Re, R. N. (2001). Stochastic frontier estimation of cost models within the hospital. Review of Economics and Statistics, 83(2), 302-309. http://dx.doi.org/10.1162/00346530151143833

Coelli, T., Perelman, S., \& Romano, E. (1999). Accounting for environmental influences in stochastic frontier models: With application to international airlines. The Journal of Productivity Analysis, 11(3), 251-273. http://dx.doi.org/10.1023/A:1007794121363

Coelli, T. J., RaoPrasada, D. S., O’Donnell C. J., \& Battese, G. E. (2005). An introduction to efficiency and productivity analysis (2nd ed.). New York: Springer.

Cohn, E., Rhine, S. L. W., \& Santos, M. C. (1989). Institutions of higher education as multi-product firms: Economies of scale and scope. Review of Economics and Statistics, 71(2), 284-290. 
http://dx.doi.org/10.2307/1926974

Cummins, J. \& Weiss, M. A. (1993). Measuring cost efficiency in the property-liability insurance industry. Journal of Banking and Finance, 17(2/3), 463-481. http://dx.doi.org/10.1016/0378-4266(93)90046-G

Fried, H., Lovell, K., \& Schmidt, S. (2008). The measurement of productivity and productive growth. New York: Oxford University Press. http://dx.doi.org/10.1093/acprof:oso/9780195183528.001.0001

Farsi, M., \& Filippini, M. (2004). An empirical analysis of cost efficiency in non-profit and public nursing homes. Annals of Public and Cooperative Economics, 75(3), 339-365. http://dx.doi.org/10.1111/j.1467-8292.2004.00255.x

Fujii, A., \& Ohta, M. (2001). Determinants and probability distribution of inefficiency in the stochastic cost frontier of Japanese hospitals. Applied Economics Letters, 8(12), 807-812. http://dx.doi.org/10.1080/13504850110046507

Huang, T., \& Wang, M. (2001). Measuring scale and scope economies in multiproduct banking? A stochastic frontier cost function approach. Applied Economics Letters, 8(3), 159-162. http://dx.doi.org/10.1080/13504850150504513

Izadi, H., Johnes, G., Oskrochi, R., \& Crouchley, R. (2002). Stochastic frontier estimation of a CES cost function: The case of higher education in Britain. Economics of Education Review, 21(1), 63-71. http://dx.doi.org/10.1016/S0272-7757(00)00044-3

Johnes, G., \& Johnes, J. (2009). Higher education institutions' cost and efficiency: Taking the decomposition a further step. Economics of Education Review, 28(1), 107-113. http://dx.doi.org/10.1016/j.econedurev.2008.02.001

Knittel, C. R. (2002). Alternative regulatory methods and firm efficiency: Stochastic frontier evidence from the U.S. electricity industry. Review of Economics and Statistics, 84(3), 530-540. http://dx.doi.org/10.1162/003465302320259529

Koshal, R., \& Koshal, M. (1999). Economies of scale and scope in higher education: A case of comprehensive universities. Economics of Education Review, 18(2), 269-277. http://dx.doi.org/10.1016/S0272-7757(98)00035-1

Kumbhakar, K., Ghosh, S., \& McGuckin, J. T. (1991). A generalized production frontier approach for estimating determinants of inefficiency in US dairy farms. Journal of Business and Economic Statistics, 9(3), 279-286. http://dx.doi.org/10.2307/1391292

Kumbhakar, S. C. (1991). The measurement and decomposition of cost-inefficiency: The translog cost system. Oxford Economic Papers, 43(4), 667-683.

Kumbhakar, S. C., \& Lovell, K. (2003). Stochastic frontier Analysis. New York: Cambridge University Press.

Lenton, P. (2008). The cost structure of higher education in further education colleges in England. Eonomomics of Education Review, 27(4), 471-482. http://dx.doi.org/10.1016/j.econedurev.2007.05.003

McMillan, M. L., \& Chan, W. H. (2006). University efficiency: A comparison and consolidation of results from stochastic and non-stochastic methods. Education Economics, 14(1), 1-30. http://dx.doi.org/10.1080/09645290500481857

Meeusen, W., \& van den Broech, J. (1977). Efficiency from Cobb-Douglas production functions with composed error. International Economic Review, 18(2), 435-444. http://dx.doi.org/10.2307/2525757

Sav, G. T. (2004). Higher education costs and scale and scope economies. Applied Economics, 36(2), 607-614. http://dx.doi.org/10.1080/0003684042000217643

Stevens, P. A. (2005). A stochastic frontier analysis of English and Welsh universities. Education Economics, 13(4), 355-374. http://dx.doi.org/10.1080/09645290500251581 
Table 1. College Means and Standard Deviations for Primary Variables, 2005-09

\begin{tabular}{|c|c|c|c|c|c|c|}
\hline Variables & \multicolumn{2}{|c|}{ Public } & \multicolumn{2}{c|}{ Private Non-Profit } & \multicolumn{2}{c|}{ Private For-Profit } \\
\hline COST, $\$$ & $4.61 \mathrm{E}+07$ & $(4.17 \mathrm{E}+07)$ & 6469798 & $(5191221)$ & 7368998 & $(8617988)$ \\
\hline TEACHING, CH & 137201 & $(131657)$ & 12746.54 & $(10173.48)$ & 26449.02 & $(27156.64)$ \\
\hline RESEARCH, $\$$ & $3.03 \mathrm{E}+07$ & $(3.01 \mathrm{E}+07)$ & 1209133 & $(1282150)$ & 995809 & $(2574832)$ \\
\hline SALARY-9M, $\$$ & 55181 & $(15112) \mathrm{v}$ & 24642 & $(23614)$ & - & - \\
\hline SALARY-12MO, $\$$ & 34782 & $(34120)$ & 38050 & $(26498)$ & 41055 & $(11185.48)$ \\
\hline FEDGRANTS, \$ & 4763299 & $(4651712)$ & 592497 & $(6280247)$ & 1624427 & $(2020199)$ \\
\hline GRAD-RATE, $\%$ & 22.354 & $(12.29585)$ & 46.73634 & $(25.90499)$ & 50.80 & $(21.74657)$ \\
\hline FACULTY-9MO, \# & 106.07 & $(91.09)$ & 11.14 & $(16.404)$ & - & - \\
\hline FACULTY-12MO, \# & 12.59 & $(31.27)$ & 8.15 & $(10.36)$ & 16.47 & $(16.79)$ \\
\hline$N$ & 3490 & & 232 & & 831 & \\
\hline
\end{tabular}

Notes: Standard deviations in parentheses. $\mathrm{CH}=$ credit hour.

Table 2. Translog Cost Frontier Estimates by Sector

\begin{tabular}{|c|c|c|c|c|c|c|}
\hline \multirow{2}{*}{$\begin{array}{c}\text { Variables } \\
\alpha_{0}\end{array}$} & \multicolumn{2}{|c|}{ Public } & \multicolumn{2}{|c|}{ Private Non-Profit } & \multicolumn{2}{|c|}{ Private For-Profit } \\
\hline & 2.478 & $(2.95)$ & -0.356 & $(-0.34)$ & 10.288 & $(7.46)$ \\
\hline TEACHING & 0.273 & $(4.12)$ & 2.019 & $(2.80)$ & 0.111 & $(2.14)$ \\
\hline RESEARCH & 0.408 & $(6.14)$ & 0.051 & $(0.31)$ & -0.043 & $(-1.19)$ \\
\hline SALARY-9MO & 0.525 & $(7.28)$ & -0.014 & $(-0.03)$ & & \\
\hline SALARY-12MO & 0.077 & $(2.86)$ & -0.043 & $(-0.09)$ & -0.439 & $(-3.31)$ \\
\hline TEACHING ${ }^{\wedge} 2$ & 0.027 & $(5.63)$ & -0.052 & $(-1.16)$ & 0.044 & $(4.19)$ \\
\hline RESEARCH^2 & 0.025 & $(38.23)$ & 0.008 & $(2.04)$ & -0.001 & $(-0.81)$ \\
\hline$S A L A R Y-9 M O^{\wedge} 2$ & 0.011 & $(3.97)$ & 0.005 & $(0.27)$ & & \\
\hline$S A L A R Y-12 M O^{\wedge} 2$ & 0.004 & (2.09) & 0.038 & $(1.83)$ & 0.083 & $(10.97)$ \\
\hline$T E A C H \times R E S$ & -0.036 & $(-8.64)$ & -0.028 & $(-1.74)$ & -0.002 & $(-0.57)$ \\
\hline$T E A C H \times S A L-9$ & 0.009 & $(3.85)$ & 0.007 & $(0.60)$ & & \\
\hline$T E A C H \times S A L-12$ & -0.008 & $(-7.85)$ & -0.034 & $(-2.89)$ & -0.061 & $(-4.16)$ \\
\hline$R E S \times S A L-9$ & -0.040 & $(-9.62)$ & 0.012 & $(1.36)$ & & \\
\hline$R E S \times S A L-12$ & 0.004 & $(4.43)$ & 0.013 & $(1.57)$ & 0.008 & $(2.98)$ \\
\hline$S A L-9 \times S A L-12$ & -0.010 & $(-3.28)$ & -0.028 & $(-1.33)$ & & \\
\hline$\delta_{0}$ & -0.836 & $(-11.03)$ & 0.251 & $(0.49)$ & -2.494 & $(-13.72)$ \\
\hline FEDGRANTS & 0.037 & $(6.59)$ & -0.084 & $(-2.40)$ & 0.269 & $(28.42)$ \\
\hline GRAD-RATE & 0.013 & $(2.18)$ & -0.012 & $(-0.24)$ & -0.038 & $(-1.47)$ \\
\hline FACULTY-9MO & 0.138 & $(18.48)$ & 0.410 & $(6.64)$ & & \\
\hline FACULTY-12MO & 0.034 & $(7.64)$ & 0.501 & $(7.83)$ & 0.014 & $(9.89)$ \\
\hline 2006-07 & 0.025 & $(2.89)$ & -0.032 & $(-0.24)$ & 0.073 & $(1.51)$ \\
\hline $2007-08$ & 0.091 & $(10.42)$ & 0.032 & $(0.28)$ & -0.017 & $(-0.34)$ \\
\hline $2008-09$ & 0.118 & 12.57) & -0.013 & $(-0.10)$ & -0.025 & $(-0.49)$ \\
\hline$\sigma^{2}$ & 0.029 & $(38.73)$ & 0.142 & $(5.92)$ & 0.222 & $(20.03)$ \\
\hline$\gamma$ & 0.262 & $(5.09)$ & 0.053 & $(0.22)$ & 0.435 & $(13.09)$ \\
\hline Log Likelihood (LL) & 1234.41 & & -106.86 & & -527.76 & \\
\hline Likelihood Ratio & 735.31 & & 99.88 & & 264.49 & \\
\hline LL Cobb-Douglas & 1266.10 & & 325.00 & & 1340.38 & \\
\hline$N$ & 3490 & & 232 & & 831 & \\
\hline
\end{tabular}

Note: Parentheses contain t-ratios. 
Table 3. Efficiency Estimates by Year and Sector

\begin{tabular}{|c|c|c|c|c|c|c|}
\hline \multirow{2}{*}{$\begin{array}{c}\text { Measure } \\
\text { Mean } \\
\end{array}$} & \multicolumn{2}{|c|}{ Public } & \multicolumn{2}{|c|}{ Private Non-Profit } & \multicolumn{2}{|c|}{ Private For-Profit } \\
\hline & 1.600 & & 1.996 & & 4.371 & \\
\hline Median & 1.579 & & 1.618 & & 3.797 & \\
\hline Minimum & 1.011 & & 1.011 & & 1.043 & \\
\hline Maximum & 2.889 & & 6.322 & & 19.643 & \\
\hline SD & 0.267 & & 1.098 & & 2.552 & \\
\hline Skewness & 0.445 & & 1.886 & & 2.258 & \\
\hline Annual Means & & Change & & Change & & Change \\
\hline 2005-06 & 1.497 & & 2.003 & & 4.376 & \\
\hline 2006-07 & 1.537 & $2.70 \%$ & 1.919 & $-4.18 \%$ & 4.443 & $1.54 \%$ \\
\hline $2007-08$ & 1.652 & $7.44 \%$ & 2.059 & $7.28 \%$ & 4.149 & $-6.61 \%$ \\
\hline 2008-09 & 1.714 & $3.77 \%$ & 2.007 & $-2.54 \%$ & 4.509 & $8.66 \%$ \\
\hline
\end{tabular}

Table 4. For-Profit Entry vs Public Inefficiency

\begin{tabular}{|c|c|c|}
\hline State & For-Profit Colleges $(\mathrm{N})$ & Public College Inefficiency (IE) \\
\hline PA & 181 & 1.765 \\
\hline $\mathrm{OH}$ & 115 & 1.556 \\
\hline NY & 73 & 1.728 \\
\hline $\mathrm{CA}$ & 69 & 1.734 \\
\hline $\mathrm{TX}$ & 41 & 1.716 \\
\hline $\mathrm{CO}$ & 38 & 1.597 \\
\hline KY & 35 & 1.628 \\
\hline MO & 29 & 1.569 \\
\hline $\mathrm{TN}$ & 28 & 1.750 \\
\hline IN & 26 & 1.490 \\
\hline FL & 23 & 1.778 \\
\hline IL & 20 & 1.574 \\
\hline LA & 19 & 1.586 \\
\hline $\mathrm{AZ}$ & 17 & 1.575 \\
\hline WV & 16 & 1.419 \\
\hline $\mathrm{PR}$ & 11 & - \\
\hline $\mathrm{CT}$ & 8 & 1.453 \\
\hline GA & 8 & 1.336 \\
\hline MA & 8 & 1.594 \\
\hline ME & 8 & 1.364 \\
\hline $\mathrm{MN}$ & 7 & 1.527 \\
\hline $\mathrm{SC}$ & 7 & 1.508 \\
\hline $\mathrm{NV}$ & 6 & 1.724 \\
\hline $\mathrm{OR}$ & 6 & 1.685 \\
\hline UT & 6 & 1.824 \\
\hline $\mathrm{AL}$ & 4 & 1.466 \\
\hline $\mathrm{KS}$ & 4 & 1.492 \\
\hline MI & 4 & 1.524 \\
\hline WY & 4 & 1.552 \\
\hline $\mathrm{NH}$ & 3 & 1.416 \\
\hline NJ & 3 & 1.596 \\
\hline \multicolumn{2}{|c|}{ Mean of 32 for-profit states } & 1.614 \\
\hline \multicolumn{2}{|c|}{ Mean of 23 other states } & 1.561 \\
\hline \multicolumn{2}{|c|}{ Correlation bet $\mathrm{N}$ and IE } & 0.350 \\
\hline
\end{tabular}

Note: "States" also include territories or outlying areas. 